\title{
The Prognostic Value of High Pretreatment Plasma D-Dimer Levels in Non-Metastatic Breast Cancer Patients with Absence of Venous Thromboembolism
}

\author{
Turgut KACAN ${ }^{1}$, Birsen YUCEL ${ }^{2}$, Seher BAHAR ${ }^{2}$, Gurol CELASUN², Mehmet M. SEKER ${ }^{3}$, \\ Nalan BABACAN ${ }^{4}$, Aykut BAHCECI ${ }^{5}$, Selen B. KACAN ${ }^{6}$, Saadettin KILICKAP ${ }^{7}$ \\ Afyonkarahisar State Hospital, Division of Medical Oncology, Afyonkarahisar \\ ${ }^{2}$ Cumhuriyet University Faculty of Medicine, Division of Radiation Oncology, Sivas \\ ${ }^{3}$ Turgut Ozal University Faculty of Medicine, Division of Medical Oncology, Ankara \\ ${ }^{4}$ Marmara University Pendik Training \& Research Hospital, Division of Medical Oncology, Istanbul \\ ${ }^{5}$ Cumhuriyet University Faculty of Medicine, Division of Medical Oncology, Sivas \\ ${ }^{6}$ Afyonkarahisar State Hospital, Division of Internal Medicine, Afyonkarahisar \\ ${ }^{7}$ Hacettepe University Faculty of Medicine, Division of Medical Oncology, Ankara, TURKEY
}

\begin{abstract}
Systemic activation of coagulation and fibrinolysis is frequently observed in cancer patients without thrombosis. Recent studies have showed the association between D-Dimer (DD) and metastatic spread and prognosis of cancer. We aimed to investigate the prognostic value of DD in patients with non metestatic breast cancer (nMBC) and evaluated the DD levels and other variables for overall survival (OS) using univariate and multivariate analyses in 448 patients. The median follow-up time was 50 months (3-151 months). There was only significant relationship between DD and distant metastases $(p=0.052)$. Performance status $(P S)(p<0.001$ and $<0.001$ ), stage ( $p<0.001$ and $<0.001)$, CEA ( $p<0.001$ and $<0.001), C A 15-3(p<0.001$ and $<0.001)$ and DD $(p<0.001$ and 0.034 ) were determined as prognostic factors for $O S$ in univariate analysis. In multivariate analysis, PS (ECOG 0 vs ECOG $1, p=$ 0.022; ECOG 0 vs ECOG $\geq 2$, ( $p<0.001$ ), stage (stage I vs stage II, $p=0.566$; stage I vs stage III, $p=0.033$ ), the $C A$ 15-3 ( $p=0.048$ ) and DD levels ( $p=0.015$ ) were determined as independent prognostic factors for OS . In conclusion, pretreatment high DD level is an important prognostic factor in patients with non metastatic breast cancer and high DD levels were associated with poor outcome.
\end{abstract}

Keywords: D-Dimer, Non-metastatic breast cancer, Prognosis

ÖZET

Tedavi Öncesi Yüksek D-Dimer Düzeylerinin Venöz Tromboembolisi Olmayan Non-Metastatik Meme Kanserli Hastalardaki Prognostik Önemi

Koagülasyon ve fibrinolizin sistemik aktivasyonu sıklıkla tromboz olmayan kanser hastalarında gözlenir. Son yıllarda yapılan çalışmalar, D-Dimer (DD) ve metastatik yayılım ve kanser prognoz arasındaki ilişkiyi göstermiştir. Biz non-metastatik meme kanseri (nMBC) olan hastalarda DD prognostik değerini araştırmayı amaçladık. D-Dimer düzeyleri, genel sağkalımı (OS) etkileyebilecek diğer değişkenler, 448 hastada tek değişkenli ve çok değişkenli kullanarak değerlendirildi. Ortalama takip süresi $58.46 \pm 1.8$ ay idi. Sadece DD ile uzak metastaz ( $p=0.052)$ arasındaki anlamlı bir ilişki saptandı. Performans durumu (PS) $(p<0.001$ ve $<0.001)$, evre $(p<0.001$ ve $<0.001)$, CEA ( $p<0.001$ ve $<0.001)$, Ca 15,3 ( $p<0.001$ ve $<0.001)$ ve DD $(p<0.001$ ve 0.034$)$ tek değişkenli analizde OS için prognostik faktörler olarak belirlendi. Çok değişkenli analizde, PS (ECOG 0 vs ECOG 1, p=0.022; ECOG 0 vs ECOG $\geq 2$ ve yüksek ( $p<0.001$ ), evre (Evre I vs evre II, s vs = 0.566; evre I vs evre III, $p=0.033)$, Ca15,3 ( $p=0.048)$ ve DD düzeyleri $(p=0.015)$ Os için bağımsız risk faktörleri olarak belirlendi. Sonuç olarak, tedavi öncesi yüksek DD düzeyleri nMBC olan hastarada önemli bir prognostik faktördür ve kötü prognoz ile ilişskilidir.

Anahtar Kelimeler: D-Dimer, Non-Metastatik meme kanseri, Prognoz 


\section{INTRODUCTION}

Breast cancer is the most common female cancer and represents a heterogeneous group of tumors which present with varied behaviors and altered response to therapy. Biological markers, hormonal status, tumor size, histological grade and subgroups status, lymph node involvement have prognostic and/or predictive value and they are important factors in selecting appropriate treatments. ${ }^{1}$

Although clinical and experimental trials have demonstrated the relationship between cancer and hemostasis, the exact mechanism is not fully understood. ${ }^{2}$ Thus, systemic activation of coagulation and hemostatic system in cancer patients without thromboembolism have been under investigation..$^{2-4}$

D-dimer, a fibrin degradation product, plays an important role in activation of coagulation, angiogenesis, progression and invasion of tumor. ${ }^{5,6}$

Cancer patients and even healthy adults with elevated D-dimer levels have higher mortality compared to general population. ${ }^{3,7}$ In addition, prognostic value of elevated D-dimer levels in lung cancer and colorectal cancer have been reported. ${ }^{8,9}$ And also it was shown that D-dimer had similar prognostic activity similar to the clinically widely used classic tumor markers. Thus, it could be accepted as a potential prognostic marker. ${ }^{10,11}$

The aim of this study was investigation of prognostic value of D-dimer in non-metastatic breast cancer patients without thromboembolism.

\section{MATERIALS AND METHODS}

Four hundred forty eight consecutive patients with histologically confirmed breast cancer and radiologically confirmed non-metastatic breast cancer admitted to Oncology Unit of Cumhuriyet University Faculty of Medicine between January 2006 and June 2013 were included in this study. All patients were over 18 years-old.

Patients with coagulation disturbances, symptomatic for thromboembolic diseases, suffering from malnutrion or who had chronic disease such as chronic kidney disease were excluded. This study was approved by the local ethical committee of Cumhuriyet University.

History and physical examination of the patients were evaluated carefully. Eastern Cooperative
Oncology Group performance status (ECOG PS) score, a complete blood cell count and chemistry analysis were recorded at the time of diagnosis. The stage was evaluated according to the 2010 TNM classification developed by the International Union against Cancer and the American Joint Committee on Cancer.

Demographic, clinical and pathological features of the patients were retrieved from the hospital records. The survival data of the patients were obtained from hospital records and the survival data of non-followed patients were obtained by calling them. Menopausal status, grade, hormone receptor status, perineural and lymphovascular invasion, stage, and nodal status of the patients were recorded to the study data base.

Disease-free survival (DFS) is defined as the period from date of diagnosis until date of first recurrence of locoregional or systemic. And overall survival (OS) was defined as the time between the date of diagnosis and last contact or death.

The first line treatments received by the patients after breast cancer diagnosis were as follows: surgical treatment was not preferred in $4(1 \%)$ patients, $275(61 \%)$ patients underwent modified radical mastectomy, and 169 (38\%) patients underwent breast conserving surgery. Axillary treatment was not preferred in $12(3 \%)$ patients, $374(83 \%)$ underwent axillary dissection, and $62(14 \%)$ patients had sentinel lymph node sampling. Neoadjuvant chemotherapy was administered to $20(5 \%)$ patients and 391 (87\%) patients received adjuvant chemotherapy. Radiotherapy and hormonal therapy was administered to 339 (76\%) and 337 (75\%) patients, respectively.

For statistical analysis, Statistical Package for Social Sciences (SPSS) for Windows 14.0 program was used. For descriptive statistics mean, standard deviation, frequency, and median were used. Categorical data were compared statistically using chi-square or Fisher's exact tests. The survival rates were calculated using the Kaplan-Meier analysis. Kaplan-Meier curves comparing DFS and OS between patient characteristics were constructed and log-rank testing was used to compare these censored outcomes. Associations between patient characteristics concerning median OS and median PFS were assessed using the log-rank test in univariable analysis. Variables were found to be 
Table 1. Demographic and histopathologic features

Demographic features $\mathrm{No}$. of

Demographic features

No. of

patients (\%)

Gender

Male

3 (1)

Female

445 (99)

Menopause status

Premenopause

$201(45)$

Postmenopause

Comorbidity

$244(55)$

$197(44)$

Localization

Unilateral

$438(98)$

Bilateral

$10(2)$

ECOG performance status

ECOGO

$300(67)$

ECOG1

127 (28)

$E C O G \geq 2$

$21(5)$

Stage

Stage I

87 (20)

$198(44)$

$163(36)$

Stage III

Histopathologic features

Histopathology

IDC

$343(77)$

ILC

19 (4)

Mikst

Other

Grade

Grade 1

105 (26)

Grade 2

$188(47)$

Grade 3

$110(27)$

Lymphovascular invasion

Negative

157 (48)

Positive

172 (52)

Perineural invasion

Negative

$200(66)$

Positive

101 (34)

Estrogen receptor

Negative

$124(28)$

Positive

$316(72)$

Progesteron receptor

Negative

148 (34)

Positive

$289(66)$

HER2

Negative

$237(57)$

Positive

$181(43)$ significant if 2 -sided $\mathrm{P}$ value was $<.05$ on univariate testing. We also employed the Cox proportional hazards model for multivariable analysis. Multivariate analysis (Cox regression analysis) was used for the evaluation of independent risk factors that had an effect on survival. The $p$ values of $\leq 0.05$ were accepted as statistically significant.

\section{RESULTS}

In this study, the data of 448 breast cancer patients were analyzed. The patients were 445 (99\%) women and $3(1 \%)$ men. The median age of patients at the time of the cancer diagnosis was 51 years (range, 18-89). Patients' demographic and histopathologic characteristics are summarized in Table 1.

The relationship between D-dimer and tumor markers, clinical stage, lymph node status, hormone status, HER2, distant metastasis and locoregional relapse were shown in Table 2. According to the table 2, there was no significant relationship between D-dimer and tumor markers, clinical stage, lymph node status, hormone status, HER2, locoregional relapse and developing distant metastasis. The median follow-up time was 50 months (3-151 months). Univariate analyses showed performance status ( $\mathrm{p}<0.001$ and $<0.001)$, stage $(\mathrm{p}<0.001$ and $<0.001)$, CEA levels ( $<<0.001$ and $<0.001)$, CA $15-3$ levels $(\mathrm{p}<0.001$ and $<0.001)$ and D-Dimer levels $(\mathrm{p}<0.001$ and 0.034$)$ were determined as prognostic factors for overall survival and Diseasefree survival in univariate analysis. The prognostic factors that affected the OS and DFS of patients in univariate survival analysis are shown Table 3.

In univariate cox regression analysis, it was found that performance status (ECOG 0 vs ECOG 1, $\mathrm{p}=$ 0.001 ; ECOG 0 vs ECOG $\geq 2, p<0.001$ ), progressing stage (III) (stage I vs stage II, $\mathrm{p}=0.80$; stage I vs stage III, $\mathrm{p}=0.012)$, CEA ( $\leq 5 \mathrm{ng} / \mathrm{mL}$ vs $>5 \mathrm{ng} /$ $\mathrm{mL}, \mathrm{p}=0.001)$, the CA $15-3$ levels $(\leq 31,3 \mathrm{U} / \mathrm{mL}$ vs $>31.3 \mathrm{U} / \mathrm{mL}, \mathrm{p}=0.001)$ and D-Dimer levels $(\leq$ $232 \mathrm{ng} / \mathrm{mL}$ vs $>232 \mathrm{ng} / \mathrm{mL} \mathrm{p}=0.002$ ) were determined as prognostic factors affecting the survival time of the patients with breast cancer for OS. Performance status (ECOG 0 vs ECOG 1, p < 0.001; ECOG 0 vs $E C O G \geq 2, p<0.001$ ), progressing stage (III) (stage I vs stage II, $\mathrm{p}=0.873$; stage I vs stage III, $\mathrm{p}=0.008$ ), CEA ( $\leq 5 \mathrm{ng} / \mathrm{mL}$ vs $>5 \mathrm{ng} /$ $\mathrm{mL}, \mathrm{p}<0.001)$, CA $15-3(\leq 31.3 \mathrm{U} / \mathrm{mL}$ vs $>31.3$ 
Table 2. Tumor markers, clinical stage, lymph node status, hormone status, HER2, developing distance metastasis, and locoregional relaps relations between D-dimer

\section{D-dimer $\leq 232 \mathrm{ng} / \mathrm{mL} \quad$ D-dimer $>232 \mathrm{ng} / \mathrm{mL} \quad$ p value \\ No. of patients (\%) No. of patients (\%)}

Developing distance metastasis

Locoregional relaps

No

Stage

Stage I

Lymph node

Negative

CEA $^{1}$

$\leq 5 \mathrm{ng} / \mathrm{mL}$

$282(69)$

CA 15-32

$\leq 31,3 \mathrm{U} / \mathrm{mL}$

$>31,3 \mathrm{U} / \mathrm{mL}$

Estrogen receptor

Progesteron receptor

HER2

$\mathrm{U} / \mathrm{mL}, \mathrm{p}<0.001)$, and D-Dimer levels ( $\leq 232 \mathrm{ng} /$ $\mathrm{mL}$ vs $>232 \mathrm{ng} / \mathrm{mL} \mathrm{p}=0.002$ ) were determined as as prognostic factors affecting the survival time of the patients with breast cancer for DFS. Results of multivariate analysis were given in Table 4.

In multivariate analysis, performance status (ECOG 0 vs ECOG 1, p= 0.022; ECOG 0 vs $\mathrm{ECOG} \geq 2, \mathrm{p}<0.001$ ), stage (stage I vs stage II, $\mathrm{p}=$ 0.566; stage I vs stage III, $\mathrm{p}=0.033$ ), the CA 15-3 levels $(\mathrm{p}=0.048)$ and D-Dimer levels $(\mathrm{p}=0.015)$ were determined as independent prognostic factors for overall survival. Performance status (ECOG 0 vs ECOG 1, p< 0.001; ECOG 0 vs ECOG $\geq 2$, p< 0.001 ), stage (stage I vs stage II, $\mathrm{p}=0.898$; stage I vs stage III, $\mathrm{p}=0.008)$, CEA, CA 15-3 ( $\mathrm{p}=0.003)$, and D-Dimer levels $(\mathrm{p}=0.080)$ were determined as independent prognostic factors for DFS. Results of multivariate analysis were given in Table 5. 
International Journal of Hematology and Oncology

Table 3. The prognostic factors that affected patients survival in univariate analysis

\begin{tabular}{|c|c|c|c|c|c|}
\hline & No. of patients & $\begin{array}{l}5 \text { years } O^{1}{ }^{1} \\
(\%)\end{array}$ & $p$ value & $\begin{array}{l}5 \text { years DFS } 2 \\
(\%)\end{array}$ & $p$ value \\
\hline \multicolumn{6}{|l|}{ Menopause status } \\
\hline Premenopause & 201 & 87 & 0.762 & 76 & 0.123 \\
\hline Postmenopause & 244 & 87 & & 80 & \\
\hline \multicolumn{6}{|l|}{ ECOG PS ${ }^{3}$} \\
\hline ECOG 0 & 300 & 92 & $<0.001$ & 85 & $<0.001$ \\
\hline ECOG 1 & 127 & 83 & & 69 & \\
\hline$E C O G \geq 2$ & 21 & 43 & & 34 & \\
\hline \multicolumn{6}{|l|}{ Grade } \\
\hline Grade 1 & 105 & 88 & 0.823 & 83 & 0.186 \\
\hline Grade 2 & 188 & 86 & & 74 & \\
\hline Grade 3 & 110 & 83 & & 77 & \\
\hline \multicolumn{6}{|l|}{$\mathrm{LV}^{4}$} \\
\hline No & 157 & 86 & 0.268 & 81 & 0.109 \\
\hline Yes & 172 & 81 & & 71 & \\
\hline \multicolumn{6}{|l|}{$\mathrm{PNI}^{5}$} \\
\hline No & 200 & 81 & 0.328 & 76 & 0.691 \\
\hline Yes & 101 & 84 & & 74 & \\
\hline \multicolumn{6}{|l|}{ Stage } \\
\hline Stage I & 75 & 93 & $<0.001$ & 87 & $<0.001$ \\
\hline Stage II & 198 & 92 & & 88 & \\
\hline Stage III & 163 & 77 & & 61 & \\
\hline \multicolumn{6}{|l|}{$\mathrm{CEA}^{6}$} \\
\hline$\leq 5 \mathrm{ng} / \mathrm{mL}$ & 408 & 89 & $<0.001$ & 82 & $<0.001$ \\
\hline$>5$ ng/mL & 32 & 74 & & 41 & \\
\hline \multicolumn{6}{|l|}{ CA $15-3^{7}$} \\
\hline$\leq 31,3 \mathrm{U} / \mathrm{mL}$ & 395 & 90 & $<0.001$ & 82 & $<0.001$ \\
\hline$>31,3 \mathrm{U} / \mathrm{mL}$ & 47 & 72 & & 51 & \\
\hline \multicolumn{6}{|l|}{ D-Dimer } \\
\hline$\leq 232 \mathrm{ng} / \mathrm{mL}$ & 305 & 90 & $<0.001$ & 81 & 0.034 \\
\hline$>232 \mathrm{ng} / \mathrm{mL}$ & 143 & 81 & & 71 & \\
\hline
\end{tabular}

\section{DISCUSSION}

D-dimer increases in various disorders including VTE, cardiovascular disease and cancer. In addition, elevated D-dimer levels were shown in healthy adult population. In one study, performed by Di Castelnuovo et al., it was shown that elevated D-Dimer level was an independent risk factor for any cause of death. ${ }^{7,12}$
Systemic activation of coagulation and hemostasis plays central role in angiogenesis, invasion, tumor progression and metastatic spread. Although pathophysiology of this activation is not completely understood, studies have been reported that observed it in cancer patients without thromboembolism. Also, it has been shown that elevated D-dimer level had an important prognostic role on prognosis. ${ }^{13-15}$ 


\begin{tabular}{|c|c|c|c|}
\hline & & Overall survival & \\
\hline & Hazard ratio & $\% 95$ confidence interval & $p$ value \\
\hline \multicolumn{4}{|l|}{ ECOG PS ${ }^{1}$} \\
\hline ECOG 0 vs 1 & 2.70 & $1.48-4.93$ & 0.001 \\
\hline ECOG 0 vs $\geq 2$ & 8.46 & $4.32-16.54$ & $<0.001$ \\
\hline \multicolumn{4}{|l|}{ Stage } \\
\hline Stage | vs || & 0.88 & $0.31-2.43$ & 0.80 \\
\hline Stage I vs III & 3.34 & $1.31-8.51$ & 0.012 \\
\hline \multicolumn{4}{|l|}{ CA $15-3^{2}$} \\
\hline$\leq 31,3 \mathrm{U} / \mathrm{mL}$ vs $\quad>31,3 \mathrm{U} / \mathrm{mL}$ & 3.97 & $2.27-6.95$ & $<0.001$ \\
\hline \multicolumn{4}{|l|}{ CEA3 } \\
\hline$\leq 5 \mathrm{ng} / \mathrm{mL}$ vs $>5 \mathrm{ng} / \mathrm{mL}$ & 3.22 & $1.61-6.46$ & 0.001 \\
\hline \multicolumn{4}{|l|}{ D-dimer } \\
\hline$\leq 232 \mathrm{ng} / \mathrm{mL}$ vs $>232 \mathrm{ng} / \mathrm{mL}$ & 2.31 & $1.37-3.89$ & 0.002 \\
\hline \multicolumn{4}{|l|}{ Disease-free survival } \\
\hline \multicolumn{4}{|l|}{ ECOG PS1 } \\
\hline ECOG 0 vs 1 & & & $<0.001$ \\
\hline ECOG 0 vs $\geq 2$ & & & $<0.001$ \\
\hline \multicolumn{4}{|l|}{ Stage } \\
\hline Stage | vs || & 0.92 & $0.33-2.54$ & 0.873 \\
\hline Stage I vs III & 3.54 & $1.39-9.00$ & 0.008 \\
\hline \multicolumn{4}{|l|}{ CA $15-3^{2}$} \\
\hline$\leq 31,3 \mathrm{U} / \mathrm{mL}$ vs $\quad>31,3 \mathrm{U} / \mathrm{mL}$ & & & $<0.001$ \\
\hline \multicolumn{4}{|l|}{$\mathrm{CEA}^{3}$} \\
\hline$\leq 5 \mathrm{ng} / \mathrm{mL}$ vs $>5 \mathrm{ng} / \mathrm{mL}$ & & & $<0.001$ \\
\hline \multicolumn{4}{|l|}{ D-dimer } \\
\hline$\leq 232 \mathrm{ng} / \mathrm{mL}$ vs $>232 \mathrm{ng} / \mathrm{mL}$ & 2.27 & $1.36-8.20$ & 0.002 \\
\hline
\end{tabular}

It was known that clinical stage, lymph node involvement were prognostic factors for breast cancer. In a study performed by Blackwell et al. ${ }^{2}$, a significant relationship was shown between elevated D-dimer levels and them. These findings indicated that high D-dimer levels could be used as an unfavorable prognostic factor, but these should not be considered lonely. In a study performed by Tas et al. ${ }^{16}$ it was shown that patients with advanced breast cancer had significant high D-dimer levels when compared to patients with early breast cancer. Prognostic importance of lymphonodal status of breast cancer has been described. Although the significant relationship existed between the presence of elevated D-dimer and involved axillary lymph nodes was reported by Blackwell et al. ${ }^{2}$, it was refuted by Fregoni et al. ${ }^{17}$ They showed that there was no correlation between plasma D-dimer levels and lymph node involvement in breast cancer. ${ }^{17}$ Like Fregoni et al., we have found that there is no significant difference between lymph node involvement and D-dimer levels. However, a borderline significance between developing distant metastasis and D-dimer was found. This relationship is likely to be a result of the relationship between the high D-dimer levels with tumor invasion. Also, 


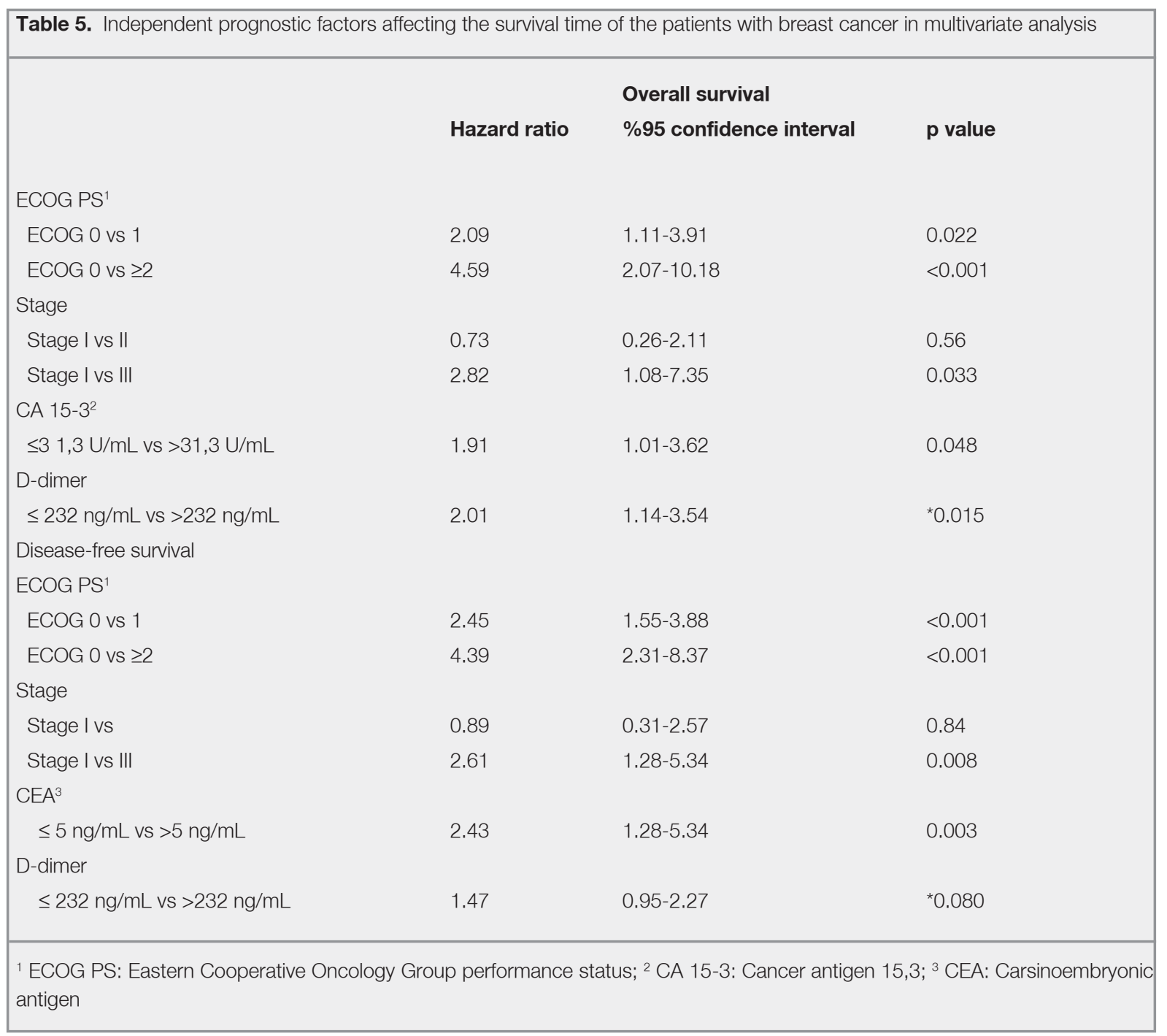

we did not find any relationship between D-Dimer levels and locoregional relapse and stage.

It is known that tumor markers have prognostic value in many types of cancers. The role of Ddimer as a tumor marker was evaluated in many studies. In a study performed by Nagy et al. ${ }^{11}$, the relationship between elevated D-dimer levels in patients with breast and colonic cancer and elevated tumor markers were shown. In another study, Pedrazzani et al. could not find any relationship in colonic cancer. ${ }^{18}$ They suggested that the most reliable prognostic factor was CEA. Oya et al. ${ }^{19}$, found a relationship between CEA and D-Dimer. Besides, the sensitivity and specificity of combination of D-Dimer and tumor marker were shown by Gadducci et al. ${ }^{20}$ Although tumor marker and elevated D-Dimer level were found as a poor prog- nostic factor in this study, we found have no correlation between them. Thus, the role of D-dimer as a tumor marker is still questionable.

Recently, studies have demonstrated that triplenegative breast cancer (TNBC) had shorter survival than non-TNBC. D-dimer levels were significantly high in patients with TNBC than non-TNBC and $\mathrm{D}$-dimer level indicates clinically progressive disease. ${ }^{21}$ Although the patients with TNBC had aggressive clinical course and had high baseline D-Dimer levels, no difference in D-dimer levels when comparing TNBC and non-TNBC patients were found in a study performed by Batschauer et al. ${ }^{22}$ Likewise, we found that there was no relationship between D-dimer levels and hormonal status and HER 2. 


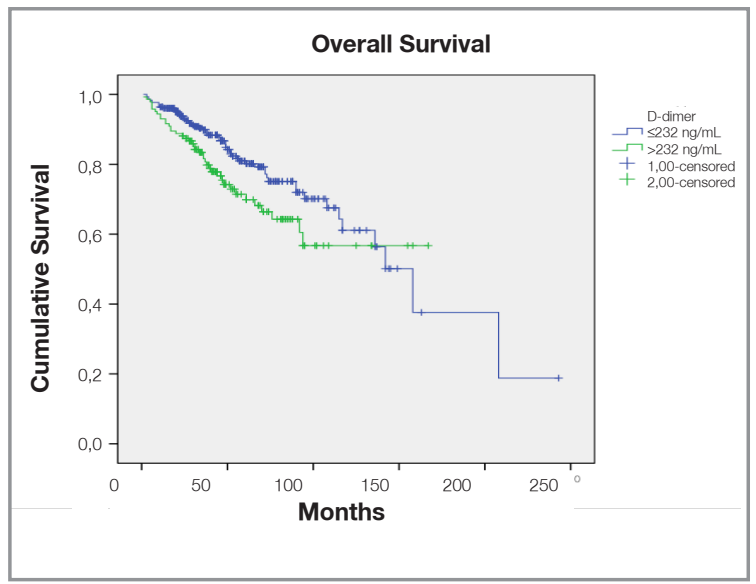

Figure 1. Correlation between D-dimer level and overall survival

Recent studies have shown a relationship between D-dimer and prognosis in cancer patients without VTE. Elevated D-dimer levels indicated poor prognosis and increased mortality risk. ${ }^{4}$ Zhang et al. ${ }^{23}$ evaluated the mortality risk of patients with lung cancer who had undergone surgery. They showed that elevated D-Dimer levels were significant prognostic factors for operable patients with lung cancer. Besides, short survival and poor response to the treatment in elevated D-dimer levels were found by Kurt et al. ${ }^{24}$ It was also supported by other studies. ${ }^{25-28}$ In our study, the patients who had baseline elevated D-Dimer levels were related with lower 5 year estimated OS rates (Figure 1) and 5 year estimated DFS rates (Figure 2). The 5 year OS rates of patients having low vs. elevated D-dimer levels were $90 \%$ vs. $81 \%$ respectively. The 5 year DFS rates of patients low vs. elevated D-dimer levels were $81 \%$ vs. $71 \%$ respectively. Besides, advanced stage, poor performance status, and high CA 15-3 are independent poor prognostic factors for OS. Advanced stage, poor performance status, and high CEA are independent poor prognostic factors for DFS.

As a conclusion, activation of hemostasis in cancer patients plays central role in angiogenesis, progression and metastatic spread and D-dimer is a biomarker that shows activation of hemostasis. Besides, it is an inexpensive and easily available blood test and elevated D-dimer level indicates poor prognosis and increased mortality risk. Thus, it could be useable as a prognostic factor in non-

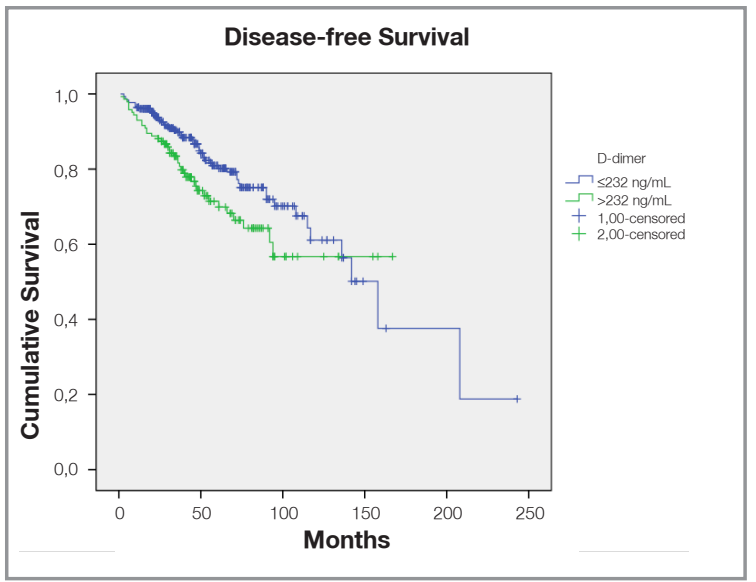

Figure 2. Correlation between D-dimer level and disease-free survival

metastatic breast cancer.

Acknowledgement: The author(s) received no financial support for the research, authorship, and/or publication of this article and declared no potential conflicts of interest.

\section{REFERENCES}

1. Cabuk D, Basaran G, Teomete M, et al. Clinical outcome of Turkish metastatic breast cancer patients with currently available treatment modalities--single center experience. Asian Pac J Cancer Prev 15: 117-122, 2014.

2. Blackwell K, Haroon Z, Broadwater G, et al. Plasma D-dimer levels in operable breast cancer patients correlate with clinical stage and axillary lymph node status. J Clin Oncol 18: 600$608,2000$.

3. Ay C, Dunkler D, Pirker R, et al. High D-dimer levels are associated with poor prognosis in cancer patients. Haematologica 97: 1158-1164, 2012.

4. Knowlson L, Bacchu S, Paneesha S, et al. Elevated D-dimers are also a marker of underlying malignancy and increased mortality in the absence of venous thromboembolism. $J$ Clin Pathol 63: 818-822, 2010.

5. Rickles FR, Edwards RL. Activation of blood coagulation in cancer: Trousseau's syndrome revisited. Blood 62: 14-31, 1983.

6. Dvorak HF, Brown LF, Detmar M, et al. Vascular permeability factor/vascular endothelial growth factor, microvascular hyperpermeability, and angiogenesis. Am J Pathol 146: 10291039, 1995.

7. Di Castelnuovo A, de Curtis A, Costanzo S, et al. Association of D-dimer levels with all-cause mortality in a healthy adult population: findings from the MOLI-SANI study. Haematologica 98: 1476-1480, 2013. 
8. Altiay G, Ciftci A, Demir M, et al. High plasma D-dimer level is associated with decreased survival in patients with lung cancer. Clin Oncol (R Coll Radiol) 19: 494-498, 2007.

9. Yamamoto M, Yoshinaga K, Matsuyama A, et al. Plasma Ddimer level as a mortality predictor in patients with advanced or recurrent colorectal cancer. Oncology 83: 10-15, 2012.

10. Nagy Z, Horvath $O$, Kadas J, et al. D-dimer as a potential prognostic marker. Pathol Oncol Res 18: 669-674, 2012.

11. Nagy Z. Biomarkers in solid tumors. Magy Onkol 57: 56-62, 2013.

12. Lorenzet R, Donati MB. Blood clotting activation, angiogenesis and tumor metastasis: any role for TFPI? Thromb Haemost 87: 928-929, 2002.

13. Mielicki WP, Tenderenda M, Rutkowski $P$, et al. Activation of blood coagulation and the activity of cancer procoagulant (EC 3.4.22.26) in breast cancer patients. Cancer Lett 146: 61-66, 1999.

14. Dirix LY, Salgado R, Weytjens R, et al. Plasma fibrin D-dimer levels correlate with tumour volume, progression rate and survival in patients with metastatic breast cancer. $\mathrm{Br} \mathrm{J}$ Cancer 86: 389-395, 2002.

15. Yigit E, Gonullu G, Yucel I, et al. Relation between hemostatic parameters and prognostic/predictive factors in breast cancer. Eur J Intern Med 19: 602-607, 2008.

16. Tas F, Kilic L, Duranyildiz D: Coagulation tests show significant differences in patients with breast cancer. Tumour Biol 35: 5985-5892, 2014.

17. Fregoni $\mathrm{V}$, Regolo L, Da Prada GA, et al. No correlation between plasma D-dimer levels and lymph node involvement in operable breast cancer. Breast 21: 220, 2012.

18. Pedrazzani C, Cerullo G, Marrelli D, et al. Is circulating Ddimer level a better prognostic indicator than CEA in resectable colorectal cancer? Our experience on 199 cases. Int J Biol Markers 25: 171-176, 2010.

19. Oya M, Akiyama Y, Yanagida T, et al. Plasma D-dimer level in patients with colorectal cancer: its role as a tumor marker. Surg Today 28: 373-378, 1998.

20. Gadducci A, Baicchi U, Marrai R, et al. Preoperative evaluation of D-dimer and CA 125 levels in differentiating benign from malignant ovarian masses. Gynecol Oncol 60: 197-202, 1996.
21. Gulben K, Berberoglu U, Cengiz A, et al. Prognostic factors affecting locoregional recurrence in patients with stage IIIB noninflammatory breast cancer. World J Surg 31: 17241730, 2007.

22. Batschauer AP, Figueiredo CP, Bueno EC, et al. D-dimer as a possible prognostic marker of operable hormone receptornegative breast cancer. Ann Oncol 21: 1267-1272, 2010.

23. Zhang PP, Sun JW, Wang XY, et al. Preoperative plasma Ddimer levels predict survival in patients with operable nonsmall cell lung cancer independently of venous thromboembolism. Eur J Surg Oncol 39: 951-956, 2013.

24. Kurt B, Kar Kurt O, Kalayci D, et al. Could plasma D-dimer levels be a predictive marker for prognosis in lung cancer? Tuberk Toraks 61: 269-274, 2013.

25. Jiang HG, Li J, Shi SB, et al. Value of fibrinogen and D-dimer in predicting recurrence and metastasis after radical surgery for non-small cell lung cancer. Med Oncol 31: 22, 2014.

26. Inal $\mathrm{T}$, Anar $\mathrm{C}$, Polat $\mathrm{G}$, et al. The prognostic value of $\mathrm{D}$-dimer in lung cancer. Clin Respir J 9: 305-913,2015.

27. Oya M, Akiyama Y, Okuyama T, et al. High preoperative plasma D-dimer level is associated with advanced tumor stage and short survival after curative resection in patients with colorectal cancer. Jpn J Clin Oncol 31: 388-394, 2001.

28. Stender MT, Larsen TB, Sorensen HT, et al. Preoperative plasma D-dimer predicts 1-year survival in colorectal cancer patients with absence of venous thromboembolism (VTE): a prospective clinical cohort study. J Thromb Haemost 10: 2027-2031, 2012

\section{Correspondence}

Dr. Turgut KAÇAN

Afyonkarahisar Devlet Hastanesi

Tibbi Onkoloji Bölümü

03100 Uydukent

AFYONKARAHISAR / TURKEY

Tel: (+90-506) 3367455

e-mail: kacanturgut@gmail.com 